\title{
Global benefits and local costs - The dilemma of tropical forest conservation: A review of the situation in Madagascar
}

\author{
REGINA NEUDERT ${ }^{1,2 *}$, JÖRG U. GANZHORN ${ }^{3}$ AND \\ FRANK W ÄTZOLD ${ }^{1}$ \\ ${ }^{1}$ Brandenburg Technical University Cottbus-Senftenberg, Postbox 101344, D-03013 Cottbus, Germany, ${ }^{2}$ Institute \\ of Botany and Landscape Ecology, Greifswald University, Soldmannstraße 15, 17489 Greifswald, Germany and \\ ${ }^{3}$ Department of Animal Ecology and Conservation, University of Hamburg, Biozentrum Grindel, \\ Martin-Luther-King Platz 3, D-20146 Hamburg, Germany
}

Date submitted: 15 October 2015; Date accepted: 25 November 2016; First published online 29

December 2016

\section{SUMMARY}

Deforestation is one of the most important conservation problems in tropical developing countries, even though cost-benefit analyses consistently show that forest conservation is economically beneficial. In Madagascar, deforestation continues at alarming rates despite numerous initiatives of international donors to increase incentives for local households to support forest conservation. In this literature review, we contrast cost-benefit analyses for forest conservation with: (1) the actual burdens and (2) the actual gains of forest conservation for rural households, generated mainly in the context of conservation projects. We show that approaches to generating direct benefits deliver less value than expected for rural communities; the benefit transfer mechanisms are insufficient as the majority of benefits are captured by other stakeholders, and increased benefit transfer is limited by structural and institutional limitations in local communities, valuation chains and in terms of governance failure at higher levels.

Keymords: deforestation, ecosystem services, benefit transfer, local communities, cost-benefit analysis, payments for ecosystem services

\section{INTRODUCTION}

Deforestation and degradation of natural forests continue to threaten the persistence of biodiversity and ecosystem services in tropical countries (Gibson et al. 2011; Vieilledent et al. 2013; WWF 2014), even though forest conservation is economically beneficial (MEA 2003; TEEB 2010). In many cases, the benefits of forest conservation exceed its costs due to the value of biodiversity and the ecosystem services provided by forests. However, while the global community enjoys most of the benefits, local populations typically bear high opportunity

*Correspondence: Dr. Regina Neudert e-mail: regina.neudert@unigreifswald.de costs (Kremen et al. 2000; Ferraro 2002; Balmford \& Whitten 2003; Hockley \& Razafindralambo 2006).

Successful forest conservation depends on the creation of forest conservation incentives for local forest users. Changing the local cost-benefit relationship is especially important in states with poor economic development and weak governance. Otherwise, forest conservation projects and protected areas risk being ineffective due to the lack of enforcement capacity and compliance of local users (Mascia et al. 2014). This long-known misfit in cost-benefit relations (Kremen et al. 2000; Ferraro 2002; Hockley \& Razafindralambo 2006) prompted government organizations (GOs) and non-government organizations (NGOs) to design and implement numerous projects to allow local populations to profit from conservation. But continuing deforestation suggests that efforts to translate the values generated by forest preservation into real local benefits have so far not been successful (Balmford \& Whitten 2003; Hanson 2012; Gardner et al. 2013).

Madagascar is a prominent example of such unfortunate developments. Its many endemic species and the high deforestation rate qualify Madagascar as a global conservation priority (Myers et al. 2000; Goodman \& Benstead 2005; Ganzhorn et al. 2014). On the other hand, Madagascar ranks 155th of 187 states in the Human Development Index and serves as a prime example of a region in which a large share of the population depends heavily on the ecosystem services provided by their environment for survival and in which the risk of malnutrition is very high (Scales 2014a; UNDP 2014; Welthungerhilfe 2014). Despite efforts by GOs and NGOs to conserve forests and improve the situation of the rural population, deforestation in Madagascar is proceeding at rates close to $1 \%$ per year, with regional highs above $2 \%$ per year (Harper et al. 2007; ONE et al. 2013; Brinkmann et al. 2014; Zinner et al. 2014). The situation in Madagascar is thus exemplary of many biodiversity-rich developing countries striving to reconcile development and conservation objectives.

Here we review the cost-benefit relationships of forest protection and the impact of recent conservation projects and other activities on the local population in Madagascar. Our review is the first of this type for the biodiversity-rich 
island. We review the envisioned costs and benefits from forest protection of three cost-benefit analyses (CBAs) and contrast them with evidence (a) on the actual burdens of forest conservation for the local population and (b) on the actual local gains from forest conservation, generated mainly in the context of conservation projects. We go beyond the existing CBAs by collecting evidence on actually generated values for all cost and benefit types considered in the CBAs and assess the potentials and impediments for the realization of the different benefit types.

CBAs quantify the costs and benefits of a project with the aim of assessing whether the project is economically beneficial to society (i.e. has a positive net present value). The net present value of a project equals the difference between the present values of the (aggregated) benefits and (aggregated) costs, which are calculated by summing up discounted future costs and benefits. A high discount rate indicates that future costs and benefits are given a low value compared to present ones. In order to be methodologically sound, all benefits and costs of a project need to be included and monetized. If no market prices exist, benefits or costs have to be estimated with appropriate methods, such as contingent valuation (willingness-to-pay or willingness-to-accept studies). In CBAs, the potential benefits of alternative use of an area are included as opportunity costs. The opportunity costs of using a resource for a particular purpose are defined as the foregone benefits of being unable to use this resource for the highest-valued alternative purposes (e.g. Hanley \& Barbier 2009; Boardman et al. 2010).

\section{METHODS}

The review is based on literature sources in English and French on the economic dimensions of forest use activities and conservation projects in Madagascar. In a first step, the Web of Science was searched for papers with the keywords 'forest conservation', 'Madagascar', 'costs', 'benefits' and terms defining different types of costs and benefits (e.g. 'charcoal', 'silk' and 'medicinal plants'). Keywords were used in different combinations mainly connected by 'and' for searching 'topics' in all years. We found that many of the papers identified through this search were not relevant to our analysis. Therefore, in a second step we manually selected those sources assessing the different types of costs or benefits either qualitatively or quantitatively. Open web-based searches and experts on forest conservation in Madagascar helped with access to books, project reports and other grey literature sources.

\section{POLITICAL AND HISTORICAL BACKGROUND OF MADAGASCAR'S CONSERVATION POLICY}

Policies to protect Madagascar's forest date back to the precolonial period in the late 19 th century. They have seen rapid expansion since the late 1980s when Madagascar received an enormous influx of development funds, including support for integrated conservation and development projects (ICDPs), community-based natural resource management (CBNRM) and payments for ecosystem services (PES) (Mercier 2012; Scales 2014a).

Since 1996, the rights to manage natural resources have been transferred to local populations under the regulations Gestion Locale Sécurisée (GELOSE; transfer of property rights to local communities). It was expected that communitybased management would solve the problem of open access to forest resources and resolve conflicts between traditional management rights and state policies. Moreover, funds for the basic communities (in Malagasy: Vondron'Olona Ifotony) should be generated through payments from the local population (Hockley \& Andriamarovololona 2007; Pollini \& Lassoie 2011). However, the actual implementation was criticized for assigning a strong role to external NGOs and external goals and neglecting the interests of local communities. In consequence, the large-scale implementation of CBNRM under the GELOSE regulations still suffers from insufficient incentives for local households to preserve the resources under their management. Thus, while CBNRM or some other form of community participation in conservation is important, actual benefit generation requires additional efforts (Hockley \& Andriamarovololona 2007; Fritz-Vietta et al. 2009). The latest phase of government environmental policies, initiated with the 'Durban vision' of President Ravalomanana in 2003, aimed to triple the area of protected zones (Corson 2014). However, the success of conservation projects has been mixed at best, and deforestation still has not been stopped (Sayer 2009; Freudenberger 2010; Brinkmann et al. 2014; Corson 2014; Zinner et al. 2014).

\section{CBA OF FOREST PROTECTION IN MADAGASCAR}

In Madagascar, CBAs for an ICDP close to Masoala National Park (Kremen et al. 2000) and for the protection of the Ranomafana-Andringitra-Pic d'Ivohibe corridor (Hockley \& Razafindralambo 2006) identified costs and benefits at the local, national and global levels. Both studies found positive net benefits for the establishment of the forest protection projects, but also significant local and national costs compared to high benefits for globally valued ecosystem services (Table 1). In these scenarios, permission for timber extraction is crucial and benefits from this activity must be captured by local communities (Kremen et al. 2000; Hockley \& Razafindralambo 2006).

A third CBA assessed the value of Madagascar's network of protected areas and also estimated a positive net present value of conservation efforts (Table 2) (Carret \& Loyer 2004). Thus, in all three CBAs, the benefits from forest products, biodiversity conservation, watershed protection and ecotourism outweigh the costs of forest protection. 
Table 1 Two cost-benefit analyses for forest conservation in Madagascar (Kremen et al. 2000; Hockley \& Razafindralambo 2006). ICDP = integrated conservation and development project; NTFP $=$ non-timber forest product.

\begin{tabular}{|c|c|c|}
\hline Data & $\begin{array}{l}\text { Kremen et al. } \\
\text { (2000) }\end{array}$ & $\begin{array}{l}\text { Hockley and } \\
\text { Razafindralambo } \\
\text { (2006) }\end{array}$ \\
\hline Study area & Masoala National Park & $\begin{array}{l}\text { Ranomafana- } \\
\text { Andringitra-Pic } \\
\text { d'Ivohibe corridor }\end{array}$ \\
\hline Scenario & $\begin{array}{l}\text { ICDP in surroundings of } \\
\text { Masoala National Park }\end{array}$ & $\begin{array}{l}\text { Protection of corridor with } \\
\text { core and buffer zone }\end{array}$ \\
\hline Scenario area size & $100000 \mathrm{ha}\left(1000 \mathrm{~km}^{2}\right)$ & $\begin{array}{l}\text { Varying sizes of buffer } \\
\text { zone; total forest area of } \\
384104 \text { ha }\end{array}$ \\
\hline Discount rate & $3 \%$ & $5 \%$ \\
\hline Time span of net present & $10-30$ years & 60 years \\
\hline
\end{tabular}

Unit

Local economy

Ecotourism

$2.7-19.1$

$29477-48013$

Sustainable community forestry

Irrigation

NTFPs

Slash-and-burn agriculture

Large-scale forestry

-1.4 to -3.2
1772

$-2288$

-5928 to -15909

-30530 to -105302
Net present value in US\$ as of $2005 \times 10^{3}$

\section{Comments}

Methodological note to Hockley and

Razafindralambo (2006): for most cost positions, the authors applied the results of previous studies to their study area ('benefits transfer' approach)

\section{Benefit/cost for scenario}

Kremen et al. (2000): benefit/cost per community

Hockley and Razafindralambo (2006): forest frontier fokontany, forest frontier commune and region; benefit/cost for scenario

Hockley and Razafindralambo (2006): direct benefits (entrance fees) and indirect benefits for the local and regional economy

Kremen et al. (2000): sale of export timber by village association (quantities based on biological inventory; sustainable harvesting rates assumed) (Kremen et al. 1999)

Hockley and Razafindralambo (2006): rice famers' willingness to pay for preventing upstream deforestation

Hockley and Razafindralambo (2006): estimates of per-household opportunity costs

Opportunity costs for households; Kremen et al. (2000): hill rice

Hockley and Razafindralambo (2006): tavy

Kremen et al. (2000): lost local employment from large-scale logging

Hockley and Razafindralambo (2006): timber; opportunity costs of full one-time extraction of economically useful timber reduced by benefits from the multiple rotation approach under the conservation scenario

\section{1-526.6 -92 250 to 11038}

$7060-42490 \quad 54612-88955$

2960-13080

$7280-28570$

$580-3400$
Benefit/cost for scenario

Hockley and Razafindralambo (2006): direct benefits (entrance fees) and indirect benefits for the national economy
Sustainable community forestry/biodiversity products

Sustained use of NTFPs

Watershed protection value

Kremen et al. (2000): watershed protection benefits to irrigated rice agriculture and to marine fisheries (prevention of sedimentation, improved water quality and balanced water supply) 
Table 1 Continued.

\begin{tabular}{|c|c|c|c|}
\hline Data & $\begin{array}{l}\text { Kremen et al. } \\
\text { (2000) }\end{array}$ & $\begin{array}{l}\text { Hockley and } \\
\text { Razafindralambo } \\
\text { (2006) }\end{array}$ & Comments \\
\hline $\begin{array}{l}\text { Internal benefit from } \\
\text { ICDP }\end{array}$ & $16730-84440$ & & \\
\hline $\begin{array}{l}\text { Donor invest- } \\
\text { ment/management } \\
\text { costs }\end{array}$ & $7810-9950$ & 7031 & $\begin{array}{l}\text { Kremen et al. (2000): donor investment based on the existing } \\
\text { Masoala ICDP budget, assuming } 5 \text { years of aid for park } \\
\text { management and } 20 \text { years for development, with } \\
\text { diminished inputs after } 10 \text { years } \\
\text { Hockley and Razafindralambo (2006): management costs, } \\
\text { assumed structure and costs of management of protected } \\
\text { area similar to state-protected area agency in Madagascar } \\
\text { (l'Association Nationale pour la Gestion des Aires } \\
\text { Protégées (ANGAP); now Madagascar National Parks) }\end{array}$ \\
\hline $\begin{array}{l}\text { Park/buffer zone } \\
\text { management costs }\end{array}$ & -8970 to -13060 & & $\begin{array}{l}\text { Kremen et al. (2000): establishment and maintenance of } \\
\text { Masoala National Park and its buffer zones }\end{array}$ \\
\hline Large-scale forestry & -92570 to -333890 & -10673 to -40179 & $\begin{array}{l}\text { Kremen et al. (2000): industrial logging concession, } \\
\text { including stumpage fees, taxes, employment and } \\
\text { infrastructure development, with the assumption that } \\
\text { foreign investors invest in minimum infrastructure, } \\
\text { primarily hire national staff, harvest all currently exported } \\
\text { hardwoods, export roundwood to mills outside of } \\
\text { Madagascar and pay all taxes and fees legally due to } \\
\text { Madagascar (full capture scenario) } \\
\text { Hockley and Razafindralambo (2006): timber; opportunity } \\
\text { costs of full one-time extraction of economically useful } \\
\text { timber reduced by benefits from the multiple rotation } \\
\text { approach under the conservation scenario }\end{array}$ \\
\hline $\begin{array}{l}\text { Slash-and-burn } \\
\text { agriculture }\end{array}$ & -6530 to -15000 & & Kremen et al. (2000): hill rice farming \\
\hline National net benefit & -82380 to -264450 & $21465-85313$ & \\
\hline Global economy & & & Benefit/cost for scenario \\
\hline Carbon sequestration & $188940-655410$ & $29654-135595$ & $\begin{array}{l}\text { Kremen et al. (2000): carbon conservation value; global value } \\
\text { ( } 20 \mathrm{US} \$ \text { /ton of carbon) for damages avoided by } \\
\text { preventing greenhouse gas emissions from deforestation } \\
\text { Hockley and Razafindralambo (2006): carbon sequestration; } \\
\text { full social cost of } \mathrm{CO}_{2} \text { emissions (US } \$ 14.42 \text { and } 44.29 / \text { ton } \\
\text { of carbon dioxide } \mathrm{CO}_{2} \text { ) }\end{array}$ \\
\hline Non-use values & & $63230-410070$ & $\begin{array}{l}\text { Hockley and Razafindralambo (2006): willingness to pay of } \\
\text { citizens in the USA and Germany to conserve biodiversity } \\
\text { of tropical rainforests }\end{array}$ \\
\hline $\begin{array}{l}\text { Donor investment in } \\
\text { ICDP/management } \\
\text { costs }\end{array}$ & -7810 to -9950 & -7031 & $\begin{array}{l}\text { Hockley and Razafindralambo (2006): management costs, } \\
\text { assumed structure and costs of management of protected } \\
\text { area similar to state-protected area agency in Madagascar } \\
\text { (ANGAP; now Madagascar National Parks) }\end{array}$ \\
\hline Bioprospecting & & -21 to 110 & $\begin{array}{l}\text { Hockley and Razafindralambo (2006): hypothetical value } \\
\text { originally estimated for tropical primary forest in Indonesia }\end{array}$ \\
\hline Global net benefit & $181130-645460$ & $92864-545774$ & \\
\hline
\end{tabular}

\section{BURDENS OF FOREST CONSERVATION FOR THE LOCAL POPULATION}

\section{Slash-and-burn agriculture}

Slash-and-burn agriculture (tavy) is the predominant system of agriculture practised in the eastern rainforest regions for rice cultivation and constitutes the main cause of deforestation and biodiversity loss in Madagascar (Minten 2003; Styger et al. 2007; Scales 2014a). To assess the cost of abandoning slash-and-burn agriculture, estimations have used household models and considered a switch to income sources in order to replace deforestation or forest use activities (Kramer et al. 
Table 2 Cost-benefit analysis of the system of protected areas in Madagascar based on Carret and Loyer (2004).

\begin{tabular}{|c|c|c|c|}
\hline Scenario information & Unit & Data & Comments \\
\hline Study area & No. protected areas & 41 & Management of system of protected areas \\
\hline Scenario area size & Million ha & 1.5 & \\
\hline Discount rate & $\%$ & 10 & \\
\hline Time span of net present values & Years & 15 & Costs and benefits calculated per hectare of protected area \\
\hline Cost of management & US\$/hectare & -41.82 & $\begin{array}{l}\text { Operational costs of protected area administration of Madagascar } \\
\text { (ANGAP; now Madagascar National Parks) and investment costs } \\
\text { (management of biodiversity and ecotourism development) }\end{array}$ \\
\hline Opportunity costs & US\$/hectare & -30.79 & $\begin{array}{l}\text { Foregone benefit of slash-and-burn agriculture, non-sustainable } \\
\text { firewood collection and use of non-timber forest products }\end{array}$ \\
\hline Conservation of biodiversity & US\$/hectare & +17.98 & $\begin{array}{l}\text { International donor payments to protected area administration } \\
\text { (ANGAP; now Madagascar National Parks) and direct donor } \\
\text { investments in management of own protected areas }\end{array}$ \\
\hline Ecotourism & US\$/hectare & +40.19 & $\begin{array}{l}\text { Entry fees of national parks and added value of nature-based } \\
\text { tourism; increase in visitors and added value per visitor assumed }\end{array}$ \\
\hline Protection of watersheds & US\$/hectare & +30.14 & $\begin{array}{l}\text { Sum of willingness to pay of rice cultivators for prevention of } \\
\text { sedimentation and balanced water supply and willingness to pay } \\
\text { of urban residents for clean drinking water (according to the } \\
\text { authors' conservative estimation) }\end{array}$ \\
\hline Discounted net benefit & US\$/hectare & +15.70 & \\
\hline
\end{tabular}

Table 3 Opportunity costs of abandoning non-sustainable forest use on the local level in Madagascar. NTFP= non-timber forest product.

\begin{tabular}{|c|c|c|c|c|}
\hline Author (year) & $\begin{array}{l}\text { Locality/year of } \\
\text { data collection }\end{array}$ & Items valued & Measurement method & $\begin{array}{l}\text { Results: US\$ per } \\
\text { household and year }\end{array}$ \\
\hline Ferraro (2002) & $\begin{array}{l}\text { Ramonafana National } \\
\text { Park/1990/National Park }\end{array}$ & $\begin{array}{l}\text { Forest use (forest products, } \\
\text { slash-and-burn agriculture) }\end{array}$ & $\begin{array}{l}\text { Opportunity costs } \\
\text { (annualized net present } \\
\text { value) }\end{array}$ & $39(19-70)$ \\
\hline $\begin{array}{l}\text { Shyamsundar and } \\
\text { Kramer (1997) }\end{array}$ & Mantadia NP/1991 & $\begin{array}{l}\text { Slash-and-burn agriculture } \\
\text { and forest products }\end{array}$ & $\begin{array}{l}\text { Opportunity costs } \\
\text { (annualized net present } \\
\text { value) in optimization } \\
\text { model }\end{array}$ & $49(28-66)$ \\
\hline $\begin{array}{l}\text { Hockley and } \\
\text { Razafindralambo } \\
(2006)\end{array}$ & $\begin{array}{l}\text { NTFP and slash-and-burn } \\
\text { agriculture estimates based on } \\
\text { Ferraro (2002), timber based } \\
\text { on workshop data }\end{array}$ & $\begin{array}{l}\text { NTFP, timber, } \\
\text { slash-and-burn agriculture }\end{array}$ & $\begin{array}{l}\text { Opportunity costs } \\
\text { (annualized net present } \\
\text { value) }\end{array}$ & 109 \\
\hline Kramer et al. (1995) & $\begin{array}{l}\text { Mantadia National Park/no } \\
\text { information }\end{array}$ & $\begin{array}{l}\text { NTFP, slash-and-burn } \\
\text { agriculture }\end{array}$ & Opportunity costs (mean) & 91 \\
\hline Kramer et al. (1995) & $\begin{array}{l}\text { Mantadia National Park/no } \\
\text { information }\end{array}$ & $\begin{array}{l}\text { Forest use (NTFP, } \\
\text { slash-and-burn agriculture) }\end{array}$ & $\begin{array}{l}\text { Willingness to accept } \\
\text { (mean) }\end{array}$ & 108 \\
\hline Minten (2003) & Maroantsetra region/2001 & Slash-and-burn agriculture & $\begin{array}{l}\text { Willingness to accept } \\
\text { (median) }\end{array}$ & 85 \\
\hline Minten (2003) & Maroantsetra region/2001 & $\begin{array}{l}\text { Forest use (NTFP, } \\
\text { slash-and-burn agriculture) }\end{array}$ & $\begin{array}{l}\text { Willingness to accept } \\
\text { (median) }\end{array}$ & 177 \\
\hline
\end{tabular}

1995; Shyamsundar \& Kramer 1997; Ferraro 2002; Hockley \& Razafindralambo 2006). Others assess the willingness to accept compensation for abandoning slash-and-burn agriculture or the use of non-timber forest products (NTFPs) (Kramer et al. 1995; Minten 2003). The opportunity costs per household are similar at different sites and probably represent the lower margin of opportunity costs since aspects such as health costs, the value of medicinal plants and social and cultural aspects were not considered (Table 3). The costs are low by western standards, but represent significant shares of the local households' total income (Shyamsundar \& Kramer 1997;
Ferraro 2002). Opportunity costs vary subject to whether the use of NTFP is allowed or not (Table 3) and can be higher for abandoning the use of NTFPs than for abandoning slash-andburn agriculture and differ between household types within and between villages (Minten 2003).

\section{Logging of high-value timber}

Non-sustainable commercial timber extraction is an important cause of deforestation in north-eastern Madagascar. Although logging targets few species, summarized under the name 
'rosewood' (Dalbergia spp. and Diospyros spp.), the damage to the whole forest is considerable (Ballet et al. 2009; Burivalova et al. 2015). Madagascar rosewood is mainly exported to China (Ballet et al. 2009; Randriamalala \& Liu 2010). An estimated 52 000 tonnes were logged in 2009 in north-eastern Madagascar, of which an estimated 36700 tonnes were shipped to China for a total export sale price estimated at US $\$ 220$ million (Randriamalala \& Liu 2010). Most of the profits from rosewood trafficking are reaped by the exporters, while the state collects only negligibly in the form of taxes and fines, and local communities profit only marginally. Taking into account the area impacted during logging, a rosewood revenue of US\$31-76 per hectare is achieved (based on Randriamalala \& Liu 2010). Rosewood trafficking has increased significantly since the 2009 coup as a result of political instability and rising corruption and has brought some species near to extinction (Barrett et al. 2010). In the two CBAs summarized earlier, the foregone benefits from timber extraction represent the most important opportunity costs on the regional and national levels (Kremen et al. 2000; Hockley \& Razafindralambo 2006). Both studies assumed that logging companies respect Malagasy laws and pay all taxes legally that are due from logging. In a more realistic approach, Kremen et al. (2000) calculated a scenario in which the state captures a third of the logging taxes. Even in this scenario, timber extraction still remains the most important factor in the opportunity costs on the national level. However, this remains speculative.

\section{Charcoal production}

Deforestation through charcoal production is high near access roads to urban centres (Minten et al. 2013) and in the dry spiny forest region in the southwest of Madagascar (Sussman et al. 1994; WWF Global 2010). The high charcoal demand in urban centres led to supply problems and longer transport routes, which induced the establishment of eucalyptus plantations (Gade \& Perkins-Belgram 1986). The charcoal sector provides income opportunities to the rural poor through production, petty retail or casual work (Minten et al. 2013). Especially in the southwest, it also offers poor rural households income opportunities during drought years (WWF Global 2010; Neudert et al. 2015). There, the situation is aggravated because charcoal cannot be produced economically with tree plantations as trees grow very slowly under the dry climate of the south-west. Despite the regional importance of charcoal production, it was not included in any CBA.

\section{GAINS FOR LOCAL POPULATIONS FROM FOREST CONSERVATION}

\section{Benefit generation}

Non-timber forest products

The rural Malagasy population uses a wide range of NTFPs. There are few Strict Nature Reserves (IUCN Category I) in Madagascar where extraction of NTFPs is prohibited (Be- maraha, Tsaratananana, Betampona and Zahamena). The majority of protected areas fall into IUCN Category II or lower, which allow utilization of forest products to some extent.

Fruits. In eastern Madagascar, about 150 plant species with edible fruits have been recorded growing in forests or on agricultural land. Wild fruits are consumed directly or sold to raise income. Commercialization of wild fruits is mainly undertaken by poorer households living closest to forests. However, the market for wild fruits remains unorganized and prices are low (Styger et al. 1999; Schatz 2001; Mananjo et al. 2010).

Yams. About 40 species of yam occur in Madagascar, most of which are endemic (Jeannoda et al. 2007). While in the dry west (Menabe and Mikea) the diversity of wild, endemic species is especially high, introduced and cultivated yams are abundant in shifting cultivation areas in the humid east (Jeannoda et al. 2007). All yam species are important food sources during the lean season and occasionally contribute to cash income, especially among poorer households (Jeannoda et al. 2007; Cheban et al. 2009; Andriamparany et al. 2015). In south-western Madagascar, sales of yams can provide weekly revenues of about US $\$ 1.9$ to collectors during the harvesting period. This amount does not capture the total value of yams, as intermediate dealers buy from collectors and sell to consumers at much higher prices (Cheban et al. 2009).

Bushmeat. Bushmeat, including wild mammals and birds, provides a complementary source of protein in addition to domestic animals. While some species are endangered and strictly protected or considered taboo $(f a d y)$, others (e.g. fruit bats and tenrecs) can be hunted legally at certain times of the year (Randrianandrianina et al. 2010; Golden et al. 2011). Some types of bushmeat represent important sources of income for the rural poor (e.g. in south-eastern Madagascar where hunters sold more lemurs than they consumed) (Randrianandrianina et al. 2010). Based on data from wildlife sales, the value of wildlife represented $57 \%$ of the annual household cash income in local communities in the Makira Natural Park and Masoala National Park. This is equivalent to an economic return of US\$0.42 per hectare and year in the harvested areas (Golden et al. 2014). In south-western Madagascar, bushmeat hunting is a secondary activity and probably has an important function as a safety net (Gardner \& Davies 2014). Although sustainable wildlife hunting can potentially generate long-term benefits for the local population, hunting has increased and is a major conservation concern (Barrett et al. 2010; Randrianandrianina et al. 2010). In addition, many of Madagascar's unique species achieve very high prices on the international pet market. Due to the mostly illegal nature of this market, the opportunity costs are difficult to estimate but are likely to be substantial (Raselimanana 2003; Ganzhorn et al. 2015).

Medicinal plants and genetic diversity. Medicinal plants play a central role in traditional medicine, but are also traded 
on international markets (Schippmann et al. 2002). In Madagascar, diverse plant species are collected mostly from the wild by rural households and traditional healers. For most medicinal plants, the exchange value associated with single plants is uncertain (Méral et al. 2006), but they represent a low-cost alternative to western medicine. For the Makira protected area, Golden et al. (2012) estimated an average of 82 treatments per year with botanical ethnomedicine from the forest having an equivalent value of US\$30.24-44.30 per household and year.

An important exported medicinal plant growing in forests is the bark of Prunus africana, which can generate more than $30 \%$ of a village's revenue (Péchard et al. 2005). The local markets for medicinal plants are segmented and prices paid to collectors for unprocessed material are low; therefore, the rural population receives only an insignificant share of the consumer price (Péchard et al. 2005; Méral et al. 2006). $P$. africana and other medicinal resources in Madagascar are increasingly threatened by unsustainable collection and deforestation (Stewart 2003).

Silk. Madagascar has a long tradition of silk production and there are a number of wild silk-producing species, especially in the highland Tapia forests and the western and northern provinces (Moat \& Smith 2007; CITE/Boss Corporation 2009). Silk production is often a secondary income source for farmers (ACI 2008; Hance 2012), but it can contribute up to $40-60 \%$ of total household income (CITE/Boss Corporation 2009). The domestic silk market is growing with a high demand for traditional silk scarves among the domestic population and tourists (ACI 2008). Numerous projects aim to enhance silk production and marketing in order to generate direct benefits for rural producers from standing forests (Razafimanantosoa et al. 2006; CITE/Boss Corporation 2009; Hance 2012). However, policy failure and uncoordinated production, processing and trade limit growth and investment (ACI 2008; Hance 2012). ACI (2008) estimated a possible output growth from 57 tonnes of silk cocoons per year to 174 tonnes per year over the next 10 years. This would generate an output value of US $\$ 3.8$ million and multiplier effects on the regional and national levels of US\$5.5 million.

\section{Sustainable timber extraction}

Kremen et al. $(1999,2000)$ calculated greater benefits in sustainable use areas from sustainable timber extraction, where a certified management system of high-value timber in cooperation with certified timber companies would translate into an annual benefit of US $\$ 130$ per household. However, it is unclear whether local communities are able to capture these benefits (Kremen et al. 1999, 2000). Apart from uncertainties on how benefits could be shared, the definition and calculation of 'sustainability', and thus the possible revenue to be obtained, is still a matter of debate (Plugge et al. 2013). Thus, the benefits outlined by Kremen et al. $(1999,2000)$ should be taken as proxies rather than concrete values.
In principle, sustainable use of forest resources, including the use of timber, is a key goal of the devolution of management under the GELOSE law. However, successful transfer of management rights and improvements in forest conditions were achieved in very few cases (McConnell \& Sweeney 2005; Raik \& Decker 2007). In particular, the economic challenges encountered by households in reducing slashand-burn agriculture were rarely addressed. Yet without the creation of viable income alternatives and reinforcement of the existing law, forest management is unlikely to be sustained (Cuvelier 1996; Raik \& Decker 2007; Urech et al. 2013).

\section{Ecotourism}

Madagascar's biodiversity is an important attraction for international tourists, with ecotourism making up the largest segment of the sector (Christie \& Crompton 2003). Tourism accounted for 6.4\% of Madagascar's GDP in 2006 (Lapeyre et al. 2007), with a growth rate of over $200 \%$ between 1990 and 2000 (Christ et al. 2003; de Groot \& Ramakrishnan 2005). In CBAs for forest protection, ecotourism is seen as a major potential source of income by capturing tourists' willingness to pay for visiting natural sites (Carret \& Loyer 2004; Ormsby $\&$ Mannle 2006). While ecotourism has become a major source of income in some regions (Wright et al. 2014), ecotourism is concentrated in very few tourist hotspots; even there, the ecotourism benefits fail to compensate the costs of forest protection at local and regional levels (Kremen et al. 2000; Hockley \& Razafindralambo 2006).

Revenues to local communities and Madagascar National Parks administration are being generated through direct marketing such as entrance fees, employment of local residents and tourist expenditures (Chaboud et al. 2004; Dolch 2008; Wollenberg et al. 2011; Sarrasin 2013). People benefitting materially from Masoala National Park had a more positive opinion of the park and were more willing to engage in its protection (Ormsby \& Mannle 2006).

\section{Policy mechanisms for paying locals for global benefits}

\section{Payments for ecosystem services}

PES can be described as voluntary contractual arrangements between 'buyers' and 'sellers' for the delivery of an ecosystem service or the provision of biodiversity (Engel et al. 2008). PES compensate local land users (sellers) for the provision of ecosystem services and biodiversity related to forest conservation through payments by national or international beneficiaries (buyers). In recent years, PES have been promoted as means of achieving conservation goals (TEEB 2010).

Carbon sequestration. Carbon conservation values that are accruing at the global level outweigh all opportunity costs on local and national levels (Kremen et al. 2000). Thus, selling carbon certificates could provide substantial incentives for conservation (Hockley \& Razafindralambo 2006), although possible benefits vary widely between forest types (Plugge et al. 
2010). Nevertheless, Madagascar has emerged as one of the prime recipients of Reduced Emissions from Deforestation and Forest Degradation (REDD) and Clean Development Mechanism payments. Since 2008, 11 REDD+ projects have been implemented or are planned in Madagascar, predominantly by global conservation NGOs such as Conservation International, the Wildlife Conservation Society and the World Wide Fund for Nature (Ferguson 2009). All REDD+ projects rely on CBNRM village associations for their implementation at the local level (Runeberg 2013). In addition, there are several other projects aiming at carbon storage in forests, but not under the umbrella of REDD (Ferguson 2009).

However, the actual transfer of benefits from carbon sequestration is still limited to a few pilot areas. The most advanced REDD+ project in Madagascar is the Makira REDD+ project implemented by the Wildlife Conservation Society. Since 2008, the Makira Carbon Company has raised US\$700 000 through the sale of carbon credits for project implementation. Nevertheless, further sale of carbon credits in that project did not take place until 2014 (Brimont \& Bidaud 2014). Another example is the Mantadia project in the east of Madagascar implemented by Conservation International (Wendland et al. 2010). The Mantadia project is a voluntary agreement on carbon storage between the 'sellers' (Madagascar's government) and the 'buyers' (the World Bank's BioCarbon Fund). Monetary benefits are paid directly to the CBNRM organization, financing local patrolling, community organization and sometimes development projects. But while the overwhelming share of grants is used for community organization (per diems, transport costs, equipment and partly ineffective local patrolling), only an insignificant share flows to those locals bearing the opportunity costs of forest conservation (Brimont \& Bidaud 2014).

Reviewing five existing REDD+ projects, Demaze (2014) criticizes the strong role of international donors and NGOs compared to the weak Malagasy state and low involvement of regional and local actors. Runeberg (2013) reports on insufficient coordination between and within projects due to a lack of leadership and institutional weaknesses at the state level.

Watershed protection. PES for watershed services are rare due to their high transaction costs (Andriamahefazafy 2010). A pilot scheme for the delivery of water services was instituted for the Antarambiby river basin providing water for the city of Fianarantsoa (c.170 000 inhabitants). Local organizations of upstream users agreed with the water supplier on reducing rice farming, refraining from using chemical fertilizers and other measures to enhance water delivery and quality. As compensation, 196 households received Madagascar Ariary (MGA) 289 million (c.US\$107 840) for a period of 2 years during the pilot phase (Andriamahefazafy 2010). This amounts to a payment of $c$. US $\$ 275$ per household and year, although data on the distribution of payments are not available. A similar scheme was implemented in 2009/2010 in the north of Madagascar in the river catchment area of Sahamazava with a contract of MGA 209 million (c.US\$77 988) for 4 years and 32 households (Andriamahefazafy 2010), translating to c. US $\$ 609$ per household per year.

Biodiversity. Madagascar's unique biodiversity has a high value for the global community (e.g. Kramer et al. 1995; Markova-Nenova \& Wätzold 2014). In the CBA of Hockley and Razafindralambo (2006), these values constitute the highest benefits for the international community.

In contrast to the large number of projects piloting the selling of carbon offsets, actual benefit transfers for non-use biodiversity values are rare in Madagascar. An incentive payment scheme of community competitions was implemented by the Durell Wildlife Conservation Trust in the Menabe region (Sommerville et al. 2010a). Awards are distributed based on the performance of CBNRM in biodiversity conservation. The project's annual rewards of $c$.US\$8500 are distributed in kind to the communities. While the distribution of benefitsin-kind in the communities was perceived as generally fair, no incentive is provided for those bearing the highest opportunity costs. Rather, behavioural changes seem to be driven by the fear of being caught as a result of increased monitoring activities (Sommerville et al. 2010a, 2010b).

A similar reward structure with participatory biodiversity management and rewards for communities was set up in the south for the Tsitongambarika Forest by Birdlife International in cooperation with the NGO Asity. Financing comes from 'biodiversity offsetting' by Rio Tinto and Rio Tinto QIT Madagascar Minerals mining ilmenite in this region (Olsen et al. 2011; Temple et al. 2012; Birdlife International 2015).

\section{Benefit sharing from genetic diversity benefits}

The biodiversity in Madagascar's ecosystems has a high economic option value in terms of its potential for the discovery of genetic and biochemical products (bioprospecting) (Jeffery 2002; Raharinirina 2009). The economic significance of genetic resources has prompted interest in these resources and stimulated their trade (Jeffery 2002; Raharinirina 2009). In the 1990s, Madagascar began to focus on the exploitation of its genetic resources, participating in international bioprospecting programmes and collaborating with laboratories and pharmaceutical companies abroad. Policies guiding access to genetic resources in accordance with the Convention on Biological Diversity (United Nations Treaty Service reference: C.N.329.1996.TREATIES-2) exist in Madagascar and were the basis of bioprospecting contracts. Two contracts, one with the International Cooperative Biodiversity Group (ICBG) Zahamena and one with ICBG Ranomafana, have since been signed, aiming to integrate the discovery of medicinal plants into research, rural development and biodiversity conservation (Raharinirina 2009). While the ICBG Zahamena considered only benefits for research institutions in Madagascar, the local communities were also supposed to benefit directly under the ICBG Ranomafana. However, real benefit sharing with local households remained questionable as the main focus was on community development measures (Raharinirina 2009). 


\section{DISCUSSION}

CBAs demonstrate large net benefits of forest conservation in Madagascar. While significant costs are incurred at local and national levels, the benefits of conservation accrue mainly to the global community, and policies still fail at enhancing and transferring benefits to local populations (Table 4). Similarly to the situation in Madagascar, this result may be found in many other biodiversity-rich developing countries striving to reconcile development and conservation objectives.

An important reason for this is that approaches to generating direct benefits often deliver less value than expected for rural communities. More specifically, shortterm benefits for the local population that are higher than slash-and-burn agriculture are rare (Méral et al. 2006; Hance 2012). Forest products such as fruits, honey, yams, bushmeat and medicinal plants are mainly used for consumption by poor rural households and often only serve as secondary sources of income, constituting a safety net when other income sources fail and delivering goods and services that are expensive to replace (Shackleton et al. 2011). Only silk production and bushmeat hunting provide employment and constitute the primary income source at selected locations (CITE/Boss Corporation 2009; Golden et al. 2014). If the sustainable management of NTFPs in forests is possible and does not contradict conservation goals, it seems appropriate to allow some degree of harvesting of NTFPs in forests and management zones of protected areas. Although the benefits are too small to outweigh the benefits of slash-and-burn agriculture, NTFPs support the livelihoods of local land users and thus might enhance acceptance of forest conservation.

Another reason for the failure of increased benefit generation for local people is that marketing opportunities for forest benefits are often insufficiently developed and, if they are developed, they often face problems of elite capture of benefits and governance failure on the national and regional levels (Ballet et al. 2009). Complex institutional and structural challenges in marketing hinder increased benefit generation from ecotourism and sustainable timber extraction. In principle, ecotourism can constitute a viable alternative source of income for local households in some highly frequented tourist destinations (Wright et al. 2014). However, the inability of the local economy to capture a substantial share of these benefits due to a lack of skills and capital and existing power relations is a major problem. Similarly, sustainable timber extraction could potentially provide significant benefits to the local population, especially in the humid forests of Madagascar, where trees achieve higher growth rates than in dry forests (Cuvelier 1996; Kremen et al. 1999).

Institutional limitations in the local communities and governance failure at higher levels also limit benefit transfer mechanisms that, in principle, could bridge the gap between the high benefits on the global level and the local costs of conservation. Under weak governance conditions, intermediary institutions and the process of overcoming high transaction costs are crucial for benefit transfer mechanisms (Cahen-Fourot \& Meral 2011). International donor organizations focus more on community benefits than on direct compensation of households and so do not provide income alternatives for individual households. Moreover, where compensation is paid, due to a lack of information and education and local power relations, the beneficiaries may not be the affected households (Poudyal et al. 2016). While it is possible to pay local households directly for not carrying out certain activities, the impact on the household in terms of livelihood security may be negative if those payments become unavailable sometime in the future (Kronenberg \& Hubacek 2013). Similarly, the benefit transfer from the bioprospecting of genetic resources would require elaborate agreements between local representatives and international agents. However, recent examples have tended to go in the direction of decoupling bioprospecting and development projects financed by the compensation payments, thus not creating incentives for forest conservation at the local level (Neimark \& Tilghman 2014).

There is no single panacea for overcoming failure to change cost-benefit relations for local land users, but rather several measures are needed. Unlike often in the past, the impact of conservation measures on local livelihoods should be addressed during the project planning phase (Scales 2014b). Appropriate actions include enhancing alternative income sources, even outside natural forests. Especially when designing benefit transfer schemes, greater emphasis has to be placed on developing income alternatives for the local population.

In line with Hanson (2012) and Scales (2014b), we recommend extensive communication between locals and conservationists to avoid misconceptions about local realities and insufficient local backing of initiatives. Conservation projects need to build on a detailed understanding of local land use systems, motivations to preserve resources and social relations inside local communities (Marie et al. 2009; Poudyal et al. 2016). They also need to consider cultural differences, especially in approaches to communication, and local power relations (Scales 2014b).

To set up viable forest use schemes (e.g. for sustainable timber harvesting or ecotourism), a number of preconditions regarding appropriate governance structures at local, regional and national levels need to be addressed. This is challenging, especially for local communities (Hajjar et al. 2011). Project periods of a few years are mostly insufficient for building organizational and social capacity within local societies for managing CBNRM initiatives independently (Urech et al. 2013). This often contradicts the planning horizons of donors and international NGOs aiming to achieve measurable success, mostly within 3 years. Thus, in striving to achieve milestones and indicators of project success on paper, the needs and concerns of local people are often of secondary concern. Moreover, long-term engagement of field-based personnel to build trust with locals, gain knowledge on local realities and facilitate participatory processes is often lacking. Thus, also on the side of donor projects and NGOs, important 
Table 4 Potential for increased benefit generation from ecosystem services for Madagascar's forests. NGO= non-governmental organization; REDD $=$ Reduced Emissions from Deforestation and Forest Degradation.

\begin{tabular}{|c|c|c|c|c|}
\hline Benefit type & Importance & Constraints & Recommendations & $\begin{array}{l}\text { Assessment of potentials for } \\
\text { increased benefit } \\
\text { generation }\end{array}$ \\
\hline \multicolumn{5}{|c|}{ Non-timber forest products } \\
\hline Fruits & $\begin{array}{l}\text { Used by local households } \\
\text { to complement diet; sale } \\
\text { of minor importance }\end{array}$ & $\begin{array}{l}\text { Market for wild fruits is } \\
\text { unorganized and prices } \\
\text { are low }\end{array}$ & $\begin{array}{l}\text { Allow and manage } \\
\text { sustainable use }\end{array}$ & $\begin{array}{l}\text { Low; not able to outweigh } \\
\text { opportunity costs from } \\
\text { foregone deforestation }\end{array}$ \\
\hline Yams & $\begin{array}{l}\text { Important food source } \\
\text { during lean season; sold } \\
\text { to a small extent }\end{array}$ & $\begin{array}{l}\text { Products of high local } \\
\text { importance; low } \\
\text { potential for } \\
\text { commercialization }\end{array}$ & $\begin{array}{l}\text { Allow and manage } \\
\text { sustainable use }\end{array}$ & $\begin{array}{l}\text { Low; not able to outweigh } \\
\text { opportunity costs from } \\
\text { foregone deforestation }\end{array}$ \\
\hline Bushmeat & $\begin{array}{l}\text { Subsistence and selling } \\
\text { activities by the rural } \\
\text { poor; safety net } \\
\text { function; important for } \\
\text { household income in few } \\
\text { places }\end{array}$ & $\begin{array}{l}\text { Hunting of threatened } \\
\text { species hinders } \\
\text { conservation; market of } \\
\text { internationally valued } \\
\text { species mostly illegal }\end{array}$ & $\begin{array}{l}\text { Manage sustainable use of } \\
\text { common species; } \\
\text { enforce and control } \\
\text { hunting bans for } \\
\text { threatened species }\end{array}$ & $\begin{array}{l}\text { Low; viable income } \\
\text { alternatives at best in few } \\
\text { selected places }\end{array}$ \\
\hline $\begin{array}{l}\text { Medicinal plants } \\
\text { and genetic } \\
\text { diversity }\end{array}$ & $\begin{array}{l}\text { Pharmaceutical and } \\
\text { spiritual value for } \\
\text { traditional medicine; } \\
\text { few species are } \\
\text { internationally valued } \\
\text { trade commodities }\end{array}$ & $\begin{array}{l}\text { For traditional values } \\
\text { exchange values } \\
\text { unknown; local markets } \\
\text { for traded species are } \\
\text { segmented; raw material } \\
\text { values are low; few } \\
\text { species threatened by } \\
\text { unsustainable harvesting }\end{array}$ & $\begin{array}{l}\text { Species of traditional } \\
\text { value: allow and manage } \\
\text { sustainable use; species } \\
\text { of commercial value: } \\
\text { increase benefit } \\
\text { generation for locals by } \\
\text { improved processing }\end{array}$ & $\begin{array}{l}\text { Low, as commercially } \\
\text { interesting species are } \\
\text { found in natural forests in } \\
\text { low densities }\end{array}$ \\
\hline Silk & $\begin{array}{l}\text { In selected places } \\
\text { secondary income } \\
\text { source for farmers; } \\
\text { demand for traditional } \\
\text { silk products growing }\end{array}$ & $\begin{array}{l}\text { Uncoordinated processing } \\
\text { and trade limit } \\
\text { production }\end{array}$ & $\begin{array}{l}\text { Continue activities for } \\
\text { improved processing, } \\
\text { trade and labelling; } \\
\text { plantations more feasible } \\
\text { than harvesting from } \\
\text { natural forests }\end{array}$ & Average in few selected places \\
\hline $\begin{array}{l}\text { Sustainable timber } \\
\text { extraction }\end{array}$ & $\begin{array}{l}\text { Timber and firewood } \\
\text { harvested frequently for } \\
\text { local demand; } \\
\text { sustainable } \\
\text { community-based } \\
\text { timber harvesting and } \\
\text { export envisioned }\end{array}$ & $\begin{array}{l}\text { Successful devolution of } \\
\text { forest management } \\
\text { seldom achieved; strong } \\
\text { incentives for } \\
\text { unsustainable timber } \\
\text { harvesting of high-value } \\
\text { species; enforcement of } \\
\text { community-based } \\
\text { schemes unlikely }\end{array}$ & $\begin{array}{l}\text { Start with pilot schemes } \\
\text { and intense long-term } \\
\text { NGO and donor } \\
\text { engagement to build } \\
\text { strong community } \\
\text { participation and } \\
\text { self-governance } \\
\text { structures }\end{array}$ & $\begin{array}{l}\text { High in selected places, but } \\
\text { considerable governance } \\
\text { challenges }\end{array}$ \\
\hline Ecotourism & $\begin{array}{l}\text { Growing market, in some } \\
\text { regions major income } \\
\text { source }\end{array}$ & $\begin{array}{l}\text { Benefits fail to cover costs } \\
\text { of conservation and } \\
\text { management of } \\
\text { protected areas; lacking } \\
\text { infrastructure and } \\
\text { qualification of domestic } \\
\text { tour operators }\end{array}$ & $\begin{array}{l}\text { Continue to promote } \\
\text { high-quality } \\
\text { nature-based tourism; } \\
\text { invest in tourism } \\
\text { infrastructure; improve } \\
\text { qualifications of } \\
\text { domestic tour operators } \\
\text { and education of local } \\
\text { guides }\end{array}$ & $\begin{array}{l}\text { High in selected tourism } \\
\text { hotspots; inappropriate as } \\
\text { 'silver bullet' for } \\
\text { conservation financing }\end{array}$ \\
\hline \multicolumn{5}{|c|}{ Payments for ecosystem services } \\
\hline $\begin{array}{l}\text { Carbon } \\
\text { sequestration }\end{array}$ & $\begin{array}{l}\text { Madagascar is prime } \\
\text { destination for REDD } \\
\text { payments; several } \\
\text { projects in place or } \\
\text { under development in } \\
\text { Madagascar }\end{array}$ & $\begin{array}{l}\text { Actual transfer limited to a } \\
\text { few pilot areas; high } \\
\text { transaction and } \\
\text { organization costs; funds } \\
\text { mainly used for paying } \\
\text { local administration } \\
\text { costs; no design of } \\
\text { income alternatives }\end{array}$ & $\begin{array}{l}\text { Pay more attention to } \\
\text { organizational setup; } \\
\text { create income } \\
\text { alternatives; pay } \\
\text { attention to } \\
\text { distributional issues } \\
\text { between local } \\
\text { households }\end{array}$ & $\begin{array}{l}\text { Highest potential for } \\
\text { large-scale implementation; } \\
\text { large-scale funding not (yet) } \\
\text { available }\end{array}$ \\
\hline
\end{tabular}


Table 4 Continued.

\begin{tabular}{|c|c|c|c|c|}
\hline Benefit type & Importance & Constraints & Recommendations & $\begin{array}{l}\text { Assessment of potentials for } \\
\text { increased benefit } \\
\text { generation }\end{array}$ \\
\hline $\begin{array}{l}\text { Watershed } \\
\text { protection }\end{array}$ & $\begin{array}{l}\text { Few pilot schemes for } \\
\text { water supply to urban } \\
\text { areas in place }\end{array}$ & $\begin{array}{l}\text { Limited to a few pilot } \\
\text { schemes; high } \\
\text { transaction and } \\
\text { organization costs }\end{array}$ & $\begin{array}{l}\text { Pay attention to } \\
\text { organizational setup } \\
\text { with long-term donor } \\
\text { involvement; pay } \\
\text { attention to } \\
\text { distributional issues } \\
\text { between local } \\
\text { households }\end{array}$ & $\begin{array}{l}\text { High, but only in places where } \\
\text { buyers of watershed } \\
\text { protection services are } \\
\text { present (i.e. near cities, rice } \\
\text { cultivation centres) }\end{array}$ \\
\hline Biodiversity & $\begin{array}{l}\text { Rare, few pilot schemes in } \\
\text { place; strong } \\
\text { participatory } \\
\text { component; commercial } \\
\text { interest of large } \\
\text { companies }\end{array}$ & $\begin{array}{l}\text { Limited to a few pilot } \\
\text { schemes; high } \\
\text { transaction and } \\
\text { organization costs; funds } \\
\text { used for paying } \\
\text { community } \\
\text { development measures; } \\
\text { no design of income } \\
\text { alternatives }\end{array}$ & $\begin{array}{l}\text { Pay attention to } \\
\text { organizational setup; } \\
\text { create income } \\
\text { alternatives; pay } \\
\text { attention to } \\
\text { distributional issues } \\
\text { between local } \\
\text { households }\end{array}$ & $\begin{array}{l}\text { High potential for large-scale } \\
\text { implementation, but } \\
\text { funding still limited }\end{array}$ \\
\hline $\begin{array}{l}\text { Benefit sharing } \\
\text { from genetic } \\
\text { diversity benefits }\end{array}$ & $\begin{array}{l}\text { Few bioprospecting } \\
\text { contracts in place under } \\
\text { the frame of } \\
\text { international agreements }\end{array}$ & $\begin{array}{l}\text { Local benefit sharing } \\
\text { questionable or aims at } \\
\text { community } \\
\text { development; link } \\
\text { between development } \\
\text { measures and values of } \\
\text { biodiversity hardly } \\
\text { visible for locals }\end{array}$ & & $\begin{array}{l}\text { Uncertain; only in few } \\
\text { selected places }\end{array}$ \\
\hline
\end{tabular}

structural preconditions for working closely with the local population need to be improved (Urech et al. 2015).

Recommendations to establish participatory processes that strongly involve the local population (Hanson 2012; Scales 2014b) also call for more interdisciplinary cooperation in the design and execution of projects, and especially the involvement of social scientists for a thorough understanding of local land use, motivations and cost-benefit relations. Longer project durations with adequate funding of field staff seem to be crucial in this regard. Thus, small pilot schemes with long-term donor engagement, a focus on people's livelihoods and participatory processes seem the most appropriate steps forward on the long path to achieving lasting success in forest conservation in Madagascar and elsewhere.

\section{ACKNOWLEDGEMENTS}

The study was carried out under the 'Accord de Collaboration' between Madagascar National Parks and the Universities of Antananarivo, Hamburg and Cottbus. The authors are grateful to the World Wide Fund for Nature (WWF) and the SuLaMa project team for assistance in collecting the literature and for supporting our work. The comments of two anonymous reviewers helped us to improve the manuscript significantly.

\section{FINANCIAL SUPPORT}

The study was funded by the German Federal Ministry of Education and Research (BMBF) as part of a project on sustainable land management of the Mahafaly Plateau (SuLaMa; grant number 01LL0914G).

\section{REFERENCES}

ACI (2008) Study on Investment and Market Opportunities in MCA-Madagascar Zones: Identification of Investment Opportunities. Bethesda, MD, USA: Agrifood Consulting International, CITE, DRN, and MDP.

Andriamparany, J. N., Brinkmann, K., Wiehle, M., Jeannoda, V. \& Buerkert, A. (2015) Modelling the distribution of four Dioscorea species on the Mahafaly Plateau of south-western Madagascar using biotic and abiotic variables. Agriculture, Ecosystems $\mathbb{E}$ Environment 212: 38-48.

Andriamahefazafy, F. (2010) Capitalisation des Résultats des Projets Pilotes en Paiement pour Services Environnementaux Hydrologiques. Antananarivo, Madagascar: C3EDM/WWF Madagascar.

Ballet, J., Lopez, P. \& Rahaga, N. (2009) L'exportation de bois précieux (Dalbergia et Diospyros) illégaux de Madagascar: 2009 et aprés? Madagascar Conservation E Development 5: 110-116.

Balmford, A. \& Whitten, T. (2003) Who should pay for tropical conservation, and how could the costs be met? Oryx 37: 238-250. 
Barrett, M.A., Brown, J.L., Morikawa, M.K., Labat, J.-N. \& Yoder, A.D. (2010) CITES designation for endangered rosewood in Madagascar. Science 328: 1109-1110.

Birdlife International (2015) Forests of Hope site - Tsitongambarika Forest, Madagascar [www document]. URL http://www.birdlife. org/worldwide/projects/forests-hope-site-tsitongambarikaforest-madagascar

Boardman, A.E., Greenberg, D.H., Vining, A.R. \& Weiner, D.L. (2010) Cost-Benefit Analysis. Boston, MA: Prentice Hall.

Brimont, L. \& Bidaud, C. (2014) Incentivising forest conservation: Payments for environmental services and reducing carbon emissions from deforestation. In: Conservation and Environmental Management in Madagascar, ed. I.R. Scales, pp. 299-319. London, UK, and New York, NY, USA: Routledge.

Brinkmann, K., Noromiarilanto, F., Ratovonamana, R.Y. \& Buerkert, A. (2014) Deforestation processes in south-western Madagascar over the past 40 years: What can we learn from settlement characteristics? Agriculture, Ecosystems E Environment 195: 231-243.

Burivalova, Z., Bauert, M.R., Hassold, S., Fatroandrianjafinonjasolomiovazo, N.T. \& Koh, L.P. (2015) Relevance of global forest change data set to local conservation: Case study of forest degradation in Masoala National Park, Madagascar. Biotropica 47: 267-274.

Cahen-Fourot, L. \& Meral, P. (2011) Gouvernance des Paiements pour Services Environnementaux (PSE) à Madagascar: l'Apport de l'Analyse Institutionnaliste. Antananarivo, Madagascar: SERENA.

Carret, J.-C. \& Loyer, D. (2004) Comment Financer Durablement les Aires Protégées à Madagascar? Apport de l'Analyse Économique. Paris, France: Agence Francaise de Développement.

Chaboud, C., Méral, P. \& Andrianambinina, D. (2004) Le modèle vertueux de l'écotourisme: mythe ou réalité? L'exemple d'Anakao et Ifaty-Mangily à Madagascar. Mondes en Développement 32: 1132.

Cheban, S.A., Rejo-Flenens, F. \& Tostain, S. (2009) Etude ethnobotanique des ignames (Dioscorea spp.) dans la foret Mikea et le couloir d'Antseva (sud-ouest de Madagascar). Malagasy Nature 2: 111-126.

Christ, C., Hillel, O., Matus, S. \& Sweeting, J. (2003) Tourism and Biodiversity: Mapping Tourism's Global Footprint. Washington, DC, USA: Conservation International.

Christie, I.T. \& Crompton, D.E. (2003) Republic of Madagascar: Tourism sector study. Africa Region Working Paper Series 63(E): 141.

CITE/Boss Corporation (2009) Etude Nationale de la Filiere Soie. Antananarivo, Madagascar: Programme de Developpement Rural Suisse-Madagascar.

Corson, C. (2014) Conservation politics in Madagascar: The expansion of protected areas. In: Conservation and Environmental Management in Madagascar, ed. I.R. Scales, pp. 193-215. London, UK, and New York, NY, USA: Routledge.

Cuvelier, A. (1996) Problems and ways of improving forest exploitation in Madagascar. In: Ecology and Economy of a Tropical Dry Forest in Madagascar, eds. J.U. Ganzhorn \& J.-P. Sorg, pp. 133-148. Goettingen, Germany: Primate Report.

de Groot, R. \& Ramakrishnan, P.S. (2005) Cultural and amenity services. In: Ecosystems and Human Well-being: Current State and Trends, Volume 1, eds. R. Hassan, R. Scholes \& N. Ash, pp. $457-$ 476. Washington, DC: Island Press.
Demaze, M.T. (2014)L'enrôlement de Madagascar dans la REDD+: Domestiquer une opportunité internationale. Vertigo 14: 1.

Dolch, R. (2008) Les efforts actuellement entrepris sont-ils suffisants pour protéger la nature d'un hot spot de la biodiversité de Madagascar? In: Paysages Naturels et Biodiversité à Madagascar, ed. S.M. Goodman, pp. 567-577. Paris, France: Muséum National d'Histoire Naturelle.

Engel, S., Pagiola, S. \& Wunder, S. (2008) Designing payments for environmental services in theory and practice: An overview of the issues. Ecology and Economy 65: 663-674.

Ferguson, B. (2009) REDD comes into fashion in Madagascar. Madagascar Conservation and Development 4: 132-137.

Ferraro, P.J. (2002) The local costs of establishing protected areas in low-income nations: Ranomafana National Park, Madagascar. Ecology and Economy 43: 261-275.

Freudenberger, K. (2010) Paradise Lost? Lessons from 25 Years of USAID Environment Programs in Madagascar. Washington, DC, USA: International Resources Group.

Fritz-Vietta, N.V.M., Röttger, C. \& Stoll-Kleemann, S. (2009) Community-based management in two biosphere reserves in Madagascar - Distinctions and similarities: What can be learned from different approaches? Madagascar Conservation $\mathcal{E}$ Development 4: 86-97.

Gade, D.W. \& Perkins-Belgram, A.N. (1986) Woodfuels, reforestation, and ecodevelopment in highland Madagascar. Geofournal 12: 365-374.

Ganzhorn, J.U., Wilmé, L. \& Mercier, J.-L. (2014) Explaining Madagascar's biodiversity. In: Conservation and Environmental Management in Madagascar, ed. I.R. Scales, pp. 17-43. London, UK, and New York, NY, USA: Routledge.

Ganzhorn, J.U., Manjoazy, T., Paeplow, O., Randrianavelona, R., Razafimanahaka, J.H., Ronto, W.M., Vogt, E., Wätzold, F. \& Walker, R.C.J. (2015) Rights to trade for species conservation: exploring the issue of the radiated tortoise in Madagascar. Environmental Conservation 42: 291-293.

Gardner, C. \& Davies, Z. (2014) Rural bushmeat consumption within multiple-use protected areas: Qualitative evidence from southwest Madagascar. Human Ecology 42: 21-34.

Gardner, C.J., Nicoll, M.E., Mbohoahy, T., Oleson, K.L.L., Ratsifandrihamanana, A.N., Ratsirarson, J., Rene, de Roland, L.A., Virah-Sawmy, M., Zafindrasilivonona, B. \& Davies, Z.G. (2013) Protected areas for conservation and poverty alleviation: Experiences from Madagascar. Fournal of Applied Ecology 50: 1289-1294.

Gibson, L., Lee, T.M., Koh, L.P., Brook, B.W., Gardner, T.A., Barlow, J., Peres, C.A., Bradshaw, C.J.A., Laurance, W.F., Lovejoy, T.E. \& Sodhi, N.S. (2011) Primary forests are irreplaceable for sustaining tropical biodiversity. Nature 478: 378381.

Golden, C.D., Bonds, M.H., Brashares, J.S., Rasolofoniaina, B.J.R. \& Kremen, C. (2014) Economic valuation of subsistence harvest of wildlife in Madagascar. Conservation Biology 28: 234-243.

Golden, C.D., Fernald, L.C.H., Brashares, J.S., Rasolofoniaina, B.J.R. \& Kremen, C. (2011) Benefits of wildlife consumption to child nutrition in a biodiversity hotspot. Proceedings of the National Academy of Sciences of the United States of America 108: 1965319656.

Golden, C.D., Rasolofoniaina, B.J.R., Anjaranirina, E.J.G., Nicolas, L., Ravaoliny, L. \& Kremen, C. (2012) Rainforest pharmacopeia in Madagascar provides high value for current local and prospective global uses. PLoS ONE 7: e41221. 
Goodman, S.M. \& Benstead, J.P. (2005) Updated estimates of biotic diversity and endemism for Madagascar. Oryx 39: 73-77.

Hajjar, R., McGrath, D.G., Kozak, R.A. \& Innes, J.L. (2011) Framing community forestry challenges with a broader lens: Case studies from the Brazilian Amazon. Fournal of Environmental Management 92:2159-2169.

Hance, J. (2012) Innovative conservation: Wild silk, endangered species, and poverty in Madagascar. Environmental News [www document]. URL https://news.mongabay.com/2012/02/ innovative-conservation-wild-silk-endangered-species-andpoverty-in-madagascar/

Hanley, N. \& Barbier, E.B. (2009) Pricing Nature: Cost-Benefit Analysis and Environmental Policy. Cheltenham, UK: Edward Elgar.

Hanson, P.W. (2012) Toward a more transformative participation in the conservation of Madagascar's natural resources. Geoforum 43: 1182-1193.

Harper, G.J., Steininger, M.K., Tucker, C.J., Juhn, D. \& Hawkins, F. (2007) Fifty years of deforestation and forest fragmentation in Madagascar. Environmental Conservation 34: 325-333.

Hockley, N.J. \& Andriamarovololona, M.M. (2007) The Economics of Community Forest Management in Madagascar: Is there a Free Lunch?: An Analysis of Transfert de Gestion. Washington, DC: USAID.

Hockley, N.J. \& Razafindralambo, R. (2006) A Social Cost-Benefit Analysis of Conserving the Ranomafana-Andringitra-Pic d'Ivohibe Corridor in Madagascar. Washington, DC, USA: Conservation International.

Jeannoda, V.H., Razanamparany, J.L., Rajaonah, M.T., Monneuse, M.O., Hladik, A. \& Hladik, C.M. (2007) Les ignames (Dioscorea spp.) de Madagascar: Espèces endémiques et formes introduites; diversité, perception, valeur nutritionnelle et systèmes de gestion durable. Revue d'Ecologie (Terre Vie) 62: 191-207.

Jeffery, M.I. (2002) Bioprospecting: Access to genetic resources and benefit-sharing under the Convention on Biodiversity and the Bonn Guidelines. Singapore Fournal of International $\mathfrak{E}$ Comparative Law 6: 747-808.

Kramer, R.A., Sharma, N. \& Munasinghe, M. (1995) Valuing Tropical Forests: Methodology and Case Study of Madagascar. Washington, DC, USA: World Bank.

Kremen, C., Niles, J.O., Dalton, M.G., Daily, G.C., Ehrlich, P.R., Fay, J.P., Grewal, D. \& Guillery, R.P. (2000) Economic incentives for rain forest conservation across scales. Science 288 : 1828-1832.

Kremen, C., Razafimahatratra, V., Guillery, R.P., Rakotomalala, J., Weiss, A. \& Ratsisompatrarivo, J.S. (1999) Designing the Masoala National Park in Madagascar based on biological and socioeconomic data. Conservation Biology 13(5): 1055-1068.

Kronenberg, J. \& Hubacek, K. (2013) Could payments for ecosystem services create an "ecosystem service curse"? Ecology and Society 18: 10 .

Lapeyre, R., Andrianambinina, D., Requier-Desjardins, D. \& Méral, P. (2007) L'Écotourisme est-il un mode durable de valorisation des ressources naturelles?: Une comparaison Namibie-Madagascar. Afrique Contemporaine 2007/2(222): 83-110.

Mananjo, H., Rejo-Fienena, F. \& Tostain, S. (2010) Les ignames endémiques (Dioscorea sp.) de la région d'Ankazoabo et de Sakaraha (Sudouest de Madagascar). In: Les Ignames Malgaches, une Ressource à Préserver et à Valoriser, eds. S. Tostain \& F. RejoFienena, pp. 42-61. Toliara, Madagascar: Université de Toliara.
Marie, C.N., Sibelet, N., Dulcire, M., Rafalimaro, M., Danthu, P. \& Carriere, S.M. (2009) Taking into account local practices and indigenous knowledge in an emergency conservation context in Madagascar. Biodiversity and Conservation 18: 2759-2777.

Markova-Nenova, N. \& Wätzold, F. (2014) PES for the poor? The preferences of buyers in developed countries. Presented at: 16th BIOECON Conference. Cambridge, UK, 21-23 September 2014.

Mascia, M.B., Pallier, S., Krithivasan, R., Roshchanka, V., Burns, D., Mlotha, M.J., Murray, D.R. \& Peng, N. (2014) Protected area downgrading; downsizing, and degazettement (PADDD) in Africa, Asia, and Latin America and the Caribbean, 1900-2010. Biological Conservation 169: 355-361.

McConnell, W.J. \& Sweeney, S.P. (2005) Challenges of forest governance in Madagascar. The Geographical fournal 171: 223238.

MEA (2003) Ecosystems and Human Wellbeing. A Framemork for Assessment. Washington, DC, USA: Island Press.

Méral, P., Raharinirina, V., Andriamahefazafy, F. \& Andrianambinina, D. (2006) La valorisation économique des forêts: Entre filière et territoire. Économie Rurale 294-295: $74-89$.

Mercier, J.-R. (2012) Revisiting deforestation in Africa (19902010): One more lost generation. Madagascar Conservation $\mathbb{E}$ Development 7: 5-8.

Minten, B. (2003) Compensation and cost of conservation payments for biodiversity. Cornell Food and Nutrition Policy Program Working Paper 142: 24.

Minten, B., Sander, K. \& Stifel, D. (2013) Forest management and economic rents: Evidence from the charcoal trade in Madagascar. Energy for Sustainable Development 17: 106-115.

Moat, J. \& Smith, P. (2007) Atlas of the Vegetation of Madagascar. London, UK: Kew Publishing, Royal Botanic Gardens.

Myers, N., Mittermeier, R.A., Mittermeier, C.G., da Fonseca, G.A.B. \& Kent, J. (2000) Biodiversity hotspots for conservation priorities. Nature 403: 853-858.

Neimark, B.D. \& Tilghman, L.M. (2014) Bioprospecting a biodiversity hotspot: The political economy of natural products drug discovery for conservation goals in Madagascar. In: Conservation and Environmental Management in Madagascar, ed. I.R. Scales, pp. 271-298. London, UK, and New York, NY, USA: Routledge.

Neudert, R., Andriamparany, J., Rakotoarisoa, M. \& Götter, J. (2015) Income diversification, wealth, education and well-being in rural south-western Madagascar: Results from the Mahafaly Region. Development Southern Africa 32: 758-784.

Olsen, N., Bishop, J. \& Anstee, S. (2011) Exploring Ecosystem Valuation to Move tomards Net Positive Impact on Biodiversity in the Mining Sector. Gland, Switzerland: IUCN.

ONE, DGF, FTM, MNP \& CI (2013) Evolution de la Couverture de Forêts Naturelles à Madagascar 2005-2010. Antananarivo, Madagascar.

Ormsby, A. \& Mannle, K. (2006) Ecotourism benefits and the role of local guides at Masoala National Park, Madagascar. Fournal of Sustainable Tourism 14: 271-287.

Péchard, G., Antona, M., Aubert, S. \& Babin, D. (2005) Ressources phytogénétiques, contrats et application de la Convention biodiversité à Madagascar: une approche prospective. Bois et Forêts des Tropiques 284: 45-58.

Plugge, D., Baldauf, T. \& Koehl, M. (2013) The global climate change mitigation strategy REDD: Monitoring costs and 
uncertainties jeopardize economic benefits. Climatic Change 119 247-259.

Plugge, D., Baldauf, T., Rakoto RatsimbaI, H., Rajoelison, G. \& Köhl, M. (2010) Combined biomass inventory in the scope of REDD (Reducing Emissions from Deforestation and Forest Degradation). Madagascar Conservation E Development 5: 23-34.

Pollini, J. \& Lassoie, J.P. (2011) Trapping farmer communities within global environmental regimes: The case of the GELOSE legislation in Madagascar. Society E Natural Resources 24: 814 830.

Poudyal, M., Ramamonjisoa, B.S., Hockley, N., Rakotonarivo, O.S., Gibbons, J.M., Mandimbiniaina, R., Rasoamanana, A. \& Jones, J.P.G. (2016) Can REDD plus social safeguards reach the 'right' people? Lessons from Madagascar. Global Environmental ChangeHuman and Policy Dimensions 37: 31-42.

Raharinirina, V. (2009) Valorisation Économique de la Biodiversité par les Contrats de Bioprospection et la Filière Huiles Essentielles: Le Cas de Madagascar. Versailles, France: Université de Versailles Saint-Quentin en Yvelines.

Raik, D.B. \& Decker, D.J. (2007) A multisector framework for assessing community-based forest management: Lessons from Madagascar. Ecology and Society 12: 14.

Randriamalala, H. \& Liu, Z. (2010) Rosewood of Madagascar: Between democracy and conservation. Madagascar Conservation E Development 5: 11-22.

Randrianandrianina, F.H., Racey, P.A. \& Jenkins, R.K.B. (2010) Hunting and consumption of mammals and birds by people in urban areas of western Madagascar. Oryx 44: 411-415.

Raselimanana, A.P. (2003) Trade in reptiles and amphibians. In: The Natural History of Madagascar, eds. S.M. Goodman \& J.P. Benstead, pp. 1564-1568. Chicago, IL, USA, and London, UK: University of Chicago Press.

Razafimanantosoa, T., Ravoahangimalala, O. \& Craig, C. (2006) Indigenous silk moth farming as a means to support Ranomafana National Park. Madagascar Conservation E Development 1: 34 39.

Runeberg, E. (2013) Decentralisation or INGOisation of REDD+? Lack of national lead in building a REDD+ strategy in Madagascar. In: Analysing REDD+: Challenges and Choices, eds. A. Angelsen, M. Brockhaus, W.D. Sunderlin \& L.V. Verchot. Bogor, Indonesia: CIFOR.

Sarrasin, B. (2013) Ecotourism, poverty and resources management in Ranomafana, Madagascar. Tourism Geographies 15: 3-24.

Sayer, J. (2009) Can conservation and development really be integrated? Madagascar Conservation ES Development 4: 9-12.

Scales, I.R. (2014a) Conservation and Environmental Management in Madagascar. London, UK, and New York, NY, USA: Routledge

Scales, I.R. (2014b) The future of conservation and development in Madagascar: Time for a new paradigm? Madagascar Conservation E Development 9: 5-12.

Schatz, G.E. (2001) Generic Tree Flora of Madagascar. London, UK, and St Louis, MO, USA: Royal Botanical Garden and Missouri Botanical Garden.

Schippmann, U., Leaman, D.J. \& Cunningham, A.B. (2002) Biodiversity and the Ecosystem Approach in Agriculture, Forestry and Fisheries. Rome, Italy: FAO, Inter-Departmental Working Group on Biological Diversity for Food and Agriculture.

Shackleton, S., Shackleton, C. \& Shanley, P., eds. (2011) NonTimber Forest Products in the Global Context. Berlin, Germany, and Heidelberg, Germany: Springer.
Shyamsundar, P. \& Kramer, R. (1997) Biodiversity conservation - At what cost? A study of households in the vicinity of Madagascar's Mantadia National Park. Ambio 26: 180-184.

Sommerville, M., Jones, J.P.G., Rahajaharison, M. \& MilnerGulland, E.J. (2010a) The role of fairness and benefit distribution in community-based payment for environmental services interventions: A case study from Menabe, Madagascar. Ecological Economics 69: 1262-1271.

Sommerville, M., Milner-Gulland, E.J., Rahajaharison, M. \& Jones, J.P.G. (2010b) Impact of a community-based payment for environmental services intervention on forest use in Menabe, Madagascar. Conservation Biology 24: 1488-1498.

Stewart, K.M. (2003) The African cherry (Prunus africana): Can lessons be learned from an over-exploited medicinal tree? Fournal of Ethnopharmacology 89: 3-13.

Styger, E., Rakotoarimanana, J.E.M., Rabevohitra, R. \& Fernandes, E.C.M. (1999) Indigenous fruit trees of Madagascar: Potential components of agroforestry systems to improve human nutrition and restore biological diversity. Agroforestry Systems 46: 289310 .

Styger, E., Rakotondramasy, H.M., Pfeffer, M.J., Fernandes, E.C.M. \& Bates, D.M. (2007) Influence of slash-and-burn farming practices on fallow succession and land degradation in the rainforest region of Madagascar. Agriculture Ecosystems $\mathbb{E}$ Environment 119: 257-269.

Sussman, R.W., Green, G.M. \& Sussman, L.K. (1994) Satellite imagery, human ecology, anthropology, and deforestation in Madagascar. Human Ecology 22: 333-354.

TEEB (2010) Integrating the ecological and economic dimensions in biodiversity and ecosystem service valuation. In: The Economics of Ecosystems and Biodiversity Ecological and Economic Foundations, ed. P. Kumar, pp. 1-37. London, UK, and Washington, DC, USA: Earthscan.

Temple, H.J., Anstee, S., Ekstrom, J., Pilgrim, J.D., Rabenantoandro, J., Ramanamanjato, J.-B., Randriatafika, F. \& Vincelette, M. (2012) Forecasting the Path tomards a Net Positive Impact on Biodiversity for Rio Tinto QMM. Gland, Switzerland: IUCN.

UNDP (2014) Human Development Indicators 2014 [www document]. URL http://hdr.undp.org/en/content/humandevelopment-index-hdi

Urech, Z.L., Sorg, J.-P. \& Felber, H.R. (2013) Challenges for community-based forest management in the KoloAla Site Manompana. Environmental Management 51: 602-615.

Vieilledent, G., Grinand, C. \& Vaudry, R. (2013) Forecasting deforestation and carbon emissions in tropical developing countries facing demographic expansion: A case study in Madagascar. Ecology and Evolution 3: 1702-1716.

Welthungerhilfe (2014) Welthunger-Index 2014. Bonn, Switzerland, Washington, DC, USA, and Dublin, Ireland: Welthungerhilfe, IFPRI and Concern Worldwide.

Wendland, K.J., Honzak, M., Portela, R., Vitale, B., Rubinoff, S. \& Randrianarisoa, J. (2010) Targeting and implementing payments for ecosystem services: Opportunities for bundling biodiversity conservation with carbon and water services in Madagascar. Ecological Economics 69: 2093-2107.

Wollenberg, K.C., Jenkins, R.K.B., Randrianavelona, R., Rampilamanana, R., Ralisata, M., Ramanandraibe, A., Ravoahangimalala, O.R. \& Vences, M. (2011) On the shoulders of lemurs: pinpointing the ecotouristic potential of 
Madagascar's unique herpetofauna. Fournal of Ecotourism 10: 101117.

Wright, P.C., Andriamihaja, B., King, S.J., Guerriero, J. \& Hubbard, J. (2014) Lemurs and tourism in Ranomafana National Park, Madagascar: Economic boom and other consequences. In: Primate Tourism: A Tool for Conservation?, eds. A.E. Russon \& J. Wallis, pp. 123-146. Cambridge: Cambridge University Press.

WWF (2014) Living Planet Report 2014. Gland, Switzerland: WWF International.
WWF Global (2010) Madagascar drought forces farmers into charcoal devastation [www document]. URL http://wwf.panda. org/?194629/Hundreds-of-Farmers-become-CharcoalProducers-in-South-Madagascar-due-to-Drought

Zinner, D., Wygoda, C., Razafimanantsoa, L., Rasoloarison, R., Andrianandrasana, H.T., Ganzhorn, J.U. \& Torkler, F. (2014) Analysis of deforestation patterns in the central Menabe, Madagascar, between 1973 and 2010. Regional Environmental Change 14: 157-166. 